\title{
キャベツ内部黒変症状と細胞死の関係
}

\author{
飯塚正英 $*$ •瀬山祥平・鈴木 修・小泉丈晴 \\ 群馬県農業技術センター３79-2224＼cjkstart群馬県伊勢崎市西小保方町
}

\section{Relationship between Internal Black Spot of Cabbage and Cell Death}

\author{
Masahide Iizuka*, Shohei Seyama, Osamu Suzuki and Takeharu Koizumi
}

Gunma Agricultural Technology Center, Nishi-obokatamachi, Isesaki, Gunma 379-2224

\begin{abstract}
The cause of internal black spot of cabbage has been speculated to be cold damage. However, in this study, we hypothesized that an acute temperature increase in the cabbage head can also be a cause, and conducted a detailed analysis on temperature change inside the cabbage head leaves and the effect of the formation of ice. Inside the cabbage leaves in winter, water droplets often froze and formed ice. Under sunny conditions, the temperature inside the cabbage leaves rose very quickly, and cell death occurred. When ice formation was induced at $-5^{\circ} \mathrm{C}$, cell death was induced within $60 \mathrm{~min}$ in all tested samples. Cell death was confirmed by tripan blue staining. Thus, we concluded that rapid thawing of frozen leaves by an acute temperature increase inside cabbage head leaves can cause damage to the cells, resulting in internal black spot.
\end{abstract}

Key Words : cold injury, ice inoculation, necrotic cell, rapid thawing

キーワード：壊死，急速融解，植水，凍害

\section{緒言}

冬季に栽培されるキャベッでは低温による寒害が発生 し, 出荷量の減少を招いている。結球期における寒害には 2 つの症状が存在する（飯塚ら，2009）. 1つは結球葉の外 葉が壊死する症状 (外葉壊死), も5 1 つが内部黒变症状で ある。外葉壊死症状は結球外葉が広く壊死し, 腐敗する症 状であり（第 1 図 A), 凍結が原因で後に腐敗病を発生させ る（青柳ら，1991; 五十嵐・大林，1985）. 一方, 内部黒変 症状は，外観上は障害がみられないが，結球葉を $3 \sim 4$ 枚 剥いだ内葉部分に，黒色の斑点が生じる（第 1 図 B ）。内部 黒変症状では収穫時に外観から発生が確認できないため, 選別が困難であり, 流通後に発覚する場合が多く問題に なっているが, 原因は不明で有効な対策はとられていない.

キャベッは低温順化によって耐凍性を獲得し（Cox・ Levitt, 1969; Kohn・Levitt, 1965)，氷点下の温度にも耐えう る植物である。しかし，脱順化によって速やかに耐凍性を 消失する（Sasaki ら，2001）。一般に生物は氷点下でも凍結 しない過冷却状態を維持する（酒井，1982）とされ，過冷 却と凍結の関係も報告されている（Rajashekar ら，1983）. 北浦（1967）は過冷却中の桑葉に植水すると直ちに過冷却

2012 年 4 月 5 日 受付. 2012 年 9 月 18 日 受理. 本報告の一部は平成 21 年度園芸学会春季大会において発表した

* Corresponding author. E-mail: i-masa@pref.gunma.lg.jp
が破壊され，葉内が凍結することから，降霜または結露の 凍結が葉の凍結を引き起こすとしている．冬季キャベッ結 球内空隙に水滴が存在する時，低温により水滴は凍結する と予想される。 また，内部黒変症状が結球葉の内層で発症 する（飯塚ら，2009）ことから，結球内空隙の温度環境も 影響している可能性がある。そこで本報では，不明とされ ている内部黒変症状の発生環境を明らかにするため，冬季 ほ場のキャベッ結球内空隙部の観察と植水による斑点形成 条件の検討を行い, 結球内空隙に生じる水滴の凍結とキャ ベッ葉の壊死との関係について究明しょうとした.

\section{材料および方法}

\section{1. 内部黒変症状発生個体の観察}

2008 年 8 月 15 日にキャベッ品種“あさしお’を播種し, 群馬県農業技術センタ一内のほ場で生育させた。栽植密度 は60 × $40 \mathrm{~cm}$ (晆幅 $\times$ 株間) で, 施肥は成分で $\mathrm{N}: \mathrm{P}_{2} \mathrm{O}_{5}: \mathrm{K}_{2} \mathrm{O}=$ $20: 24: 20 \mathrm{~kg} / 10 \mathrm{a}$ を施用した. 2009 年 2 月 3 日午前 9 時に 結球した 5 個体（平均結球重 $1,132 \mathrm{~kg}$ ) の外葉を剥ぎ，内 部の様子を観察した。観察時の天候は晴，気温 $-1.3^{\circ} \mathrm{C}$ ，湿 度 $55 \%$ RH であった。

\section{2. キャベツ結球内部の温度変化}

2009 年 8 月 2 日にキャベッ品種 ‘あさしお’を播種し, 群馬県農業技術センタ一内の湯で生育させた。栽植密度 は $60 \times 40 \mathrm{~cm}$ (畦幅 $\times$ 株間) で, 施肥は成分で $\mathrm{N}: \mathrm{P}_{2} \mathrm{O}_{5}: \mathrm{K}_{2} \mathrm{O}=$ $20: 24: 20 \mathrm{~kg} / 10 \mathrm{a}$ を施用した。 2010 年 1 月 9 日と 1 月 12 
日に, 結球した 1 個体（結球重 $1,788 \mathrm{~kg}$ ）の表面と, 表面 から 3 枚目と 4 枚目の空隙, 6 枚目と 7 枚目の空隙, 10 枚 目と 11 枚目の空陌の温度を測定した. 空隙の温度は直径 $2 \mathrm{~mm}$ の針金を用いて導入穴を開け，温度記録計（TR-52, ティアンドデイ）のセンサー部分を挿入し，1 時間ごとの 温度変化を記録した. センサー到達点は調査後にキャベッ を切断して確認した.

\section{3. 植水がキャベツ葉の斑点形成に及ぼす影響}

供試材料としてキャベッ品種“あさしお’を用いた. 2009 年 9 月 28 日に播種し, 4 週間後に直径 $9 \mathrm{~cm}$ のポリポット に移植して生育させ，草丈 $12 \sim 14 \mathrm{~cm}$, 葉数 $5 \sim 7$ 枚の 幼苗を用いた。 11 月 30 日から 7 日間 $5^{\circ} \mathrm{C}, 8,0001 \mathrm{x}, 12$ 時 間日長のグロースチャンバーで低温順化処理した後, 北浦 （1967）の方法に準じて葉面にスプレーで水滴を散布し, $-5^{\circ} \mathrm{C}$ の低温室に入れて植水した植水処理区と植水せずに $-5^{\circ} \mathrm{C}$ の低温室に入れた無処理区とで斑点形成に及ぼす影 響を比較した. 調査方法はそれぞれ 10 株ずつ 15 分, 30 分, 45 分および 60 分後に低温室から取り出して, $20^{\circ} \mathrm{C}, 8,000 \mathrm{~lx}$, 12 時間日長のグロースチャンバーで 3 日間処理して葉上の 斑点形成を観察した. また, 植氷処理後の温度条件が斑点 形成に及ぼす影響について, $20^{\circ} \mathrm{C} て ゙ 3$ 日間処理したものを 急速融解区, $5^{\circ} \mathrm{C} 60$ 分の後 $20^{\circ} \mathrm{C}$ で 3 日間処理したものを $5^{\circ} \mathrm{C} \rightarrow 20^{\circ} \mathrm{C}$ 区, $0^{\circ} \mathrm{C} 60$ 分の後 $20^{\circ} \mathrm{C}$ で 3 日間処理したもの を $0^{\circ} \mathrm{C} \rightarrow 20^{\circ} \mathrm{C}$ 区, $0^{\circ} \mathrm{C} 60$ 分の後, $5^{\circ} \mathrm{C}$ で 60 分, さらに $20^{\circ} \mathrm{C}$ で3 日間経過したものを緩融解区とし，それぞれ 10 株を 12時間日長のグロースチャンバーで処理して葉上の斑点形 成を観察した. 斑点は, 形成程度により $0 \sim 3$ の指数で分 類され， 1 葉中の形成度により評価した. 斑点形成度 $=\Sigma$ (指数 $\times$ 株数) $/ 3 \times$ 調査株数. 指数は 0 : 斑点なし, 1 : 斑 点形成数少（斑点が $1 / 3$ 以下の面積で認められる），2：斑
点形成数中（斑点が $1 / 3 \sim 2 / 3$ の面積で認められる）, 3 : 斑 点形成数多（ほぼ全葉で斑点形成が認められる）とした.

\section{4. 植水による細胞死の再現}

供試材料としてキャベッ品種“あさし拈”を用いた. 2011 年 3 月 2 日に播種し, 草丈 $12 \sim 14 \mathrm{~cm}$, 葉数 $5 \sim 7$ 枚の幼 苗 5 株ならびに 2011 年 8 月 2 日に播種し, 翌年 1 月 11 日 まで淿場で生育させた結球株（結球重 $1,654 \mathrm{~kg}$ ）の外葉か ら 3 枚目を用いた. 幼苗は, 播種 4 週間後に直径 $9 \mathrm{~cm}$ のポ リポットに移植して生育させ，5月 9 日から 7 日間 $5^{\circ} \mathrm{C}, 12$ 時間日長のグロースチャンバーで低温順化処理した．幼苗 の植水方法は葉面にスプレーで水滴を散布し, $-5^{\circ} \mathrm{C}$ の低温 室に入れた. 植氷処理した幼苗を 45 分後に取り出して, $20^{\circ} \mathrm{C}$ のグロースチャンバーで 24 時間処理した. 1 株から 2 枚の葉を用いて Koch・Slusarenko（1990）に従ってトリ パンブルー染色を行い，細胞死を確認した．すなわち，約 $2 \times 2 \mathrm{~cm}$ に切り抜いた葉をラクトフェノールトリパンブ ルー溶液（乳酸 $10 \mathrm{mL，グリセロール} 10 \mathrm{mL，フェノール}$ $10 \mathrm{~mL}$ ，トリパンブルー $10 \mathrm{mg}$ ) で染色した後, クローラル ハイドレート溶液（クローラルハイドレート $25 \mathrm{~g}$, 蒸留水 $10 \mathrm{~mL}$ ) で洗浄し，実体顕微鏡（SZH10，オリンパス）で 観察した.

\section{結 果}

\section{1. 内部黒変症状発生個体の観察}

5 個体すべての個体で，結球内部の葉面に多数の水塊が 認められた. 水塊と水滴が混在している部分もあり，葉面 には変色した痕も認められた（第 2 図）．5 個体中 2 個体で 内部黒変症状が発生していた（第 3 図）。

\section{2. キャベツ結球内部の温度変化}

2010 年 1 月 9 日の観察地は晴天でキャベッ近傍の䨌囲気
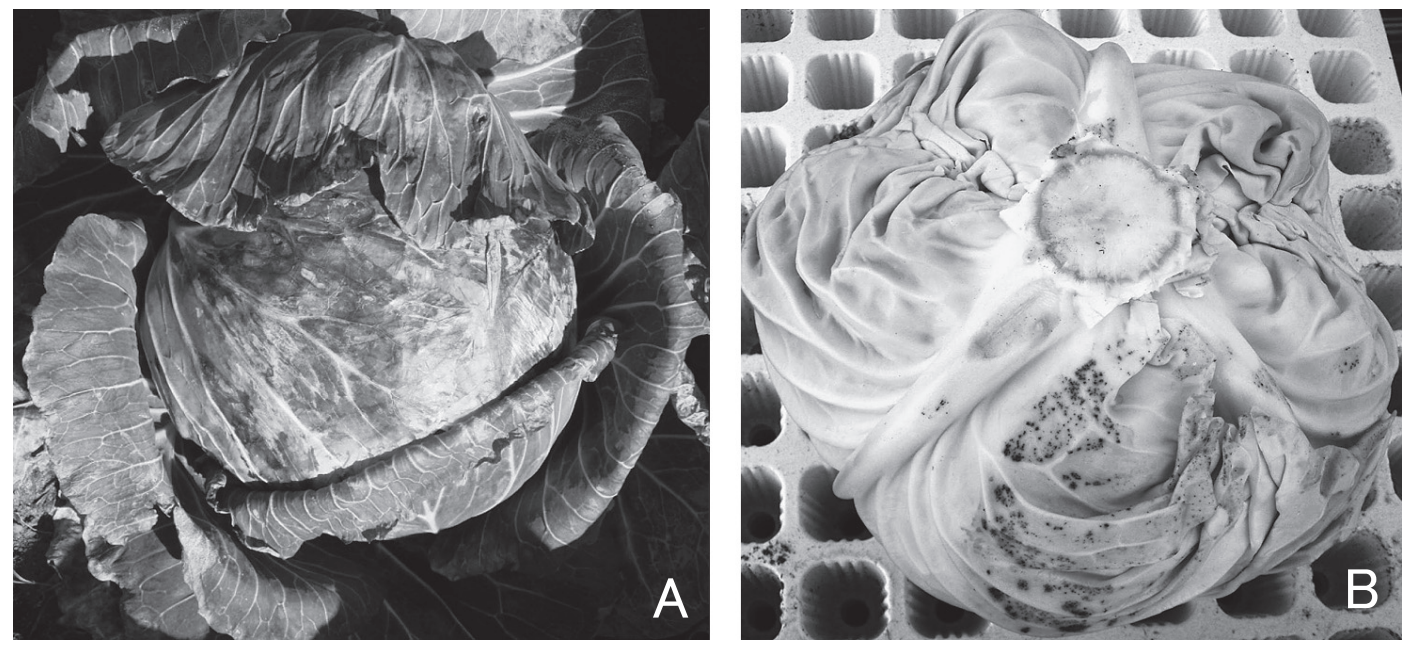

第1図 冬季栽培キャベッにおける寒害症状

A : 外葉壊死症状

B : 内部黒変症状

2009 年 1 月 13 日, 群馬県農業技術センターほ場で撮影

品種は“あさしお’ 


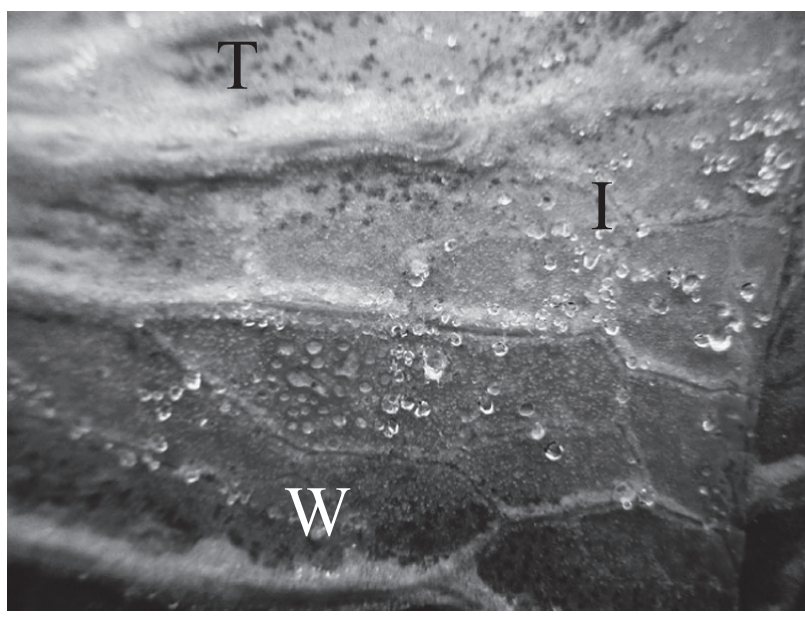

第 2 図キャベッ結球葉内部の水結 $\mathrm{W}$ : 水滴, $\mathrm{I}$ : 水塊, $\mathrm{T}$ : 変色痕 2009 年 2 月 3 日, 群馬県農業技術センターほ場で撮影 品種は“あさし拈”

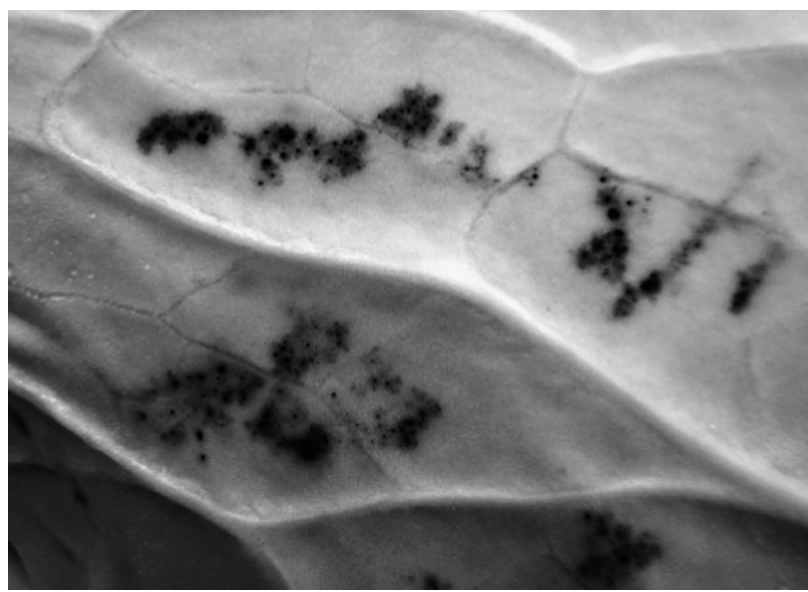

第 3 図キャベッ結球葉内部の黒変症状

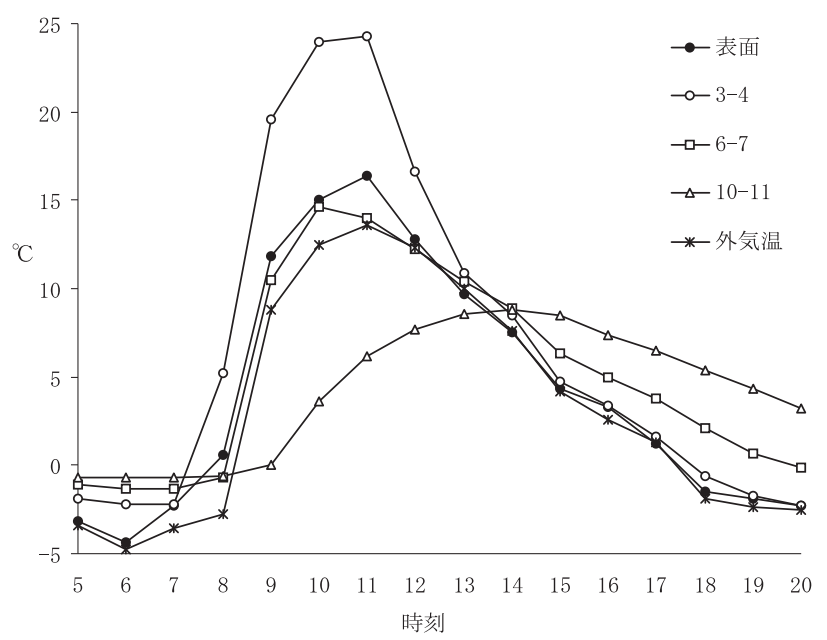

第 4 図 晴天時のキャベッ結球内部の温度変化（2010 年 1 月 9 日）

3-4:3 枚目と 4 枚目の空隙 6-7 : 6 枚目々 7 枚目の空隙 10-11：10 枚目と 11 枚目の空隙

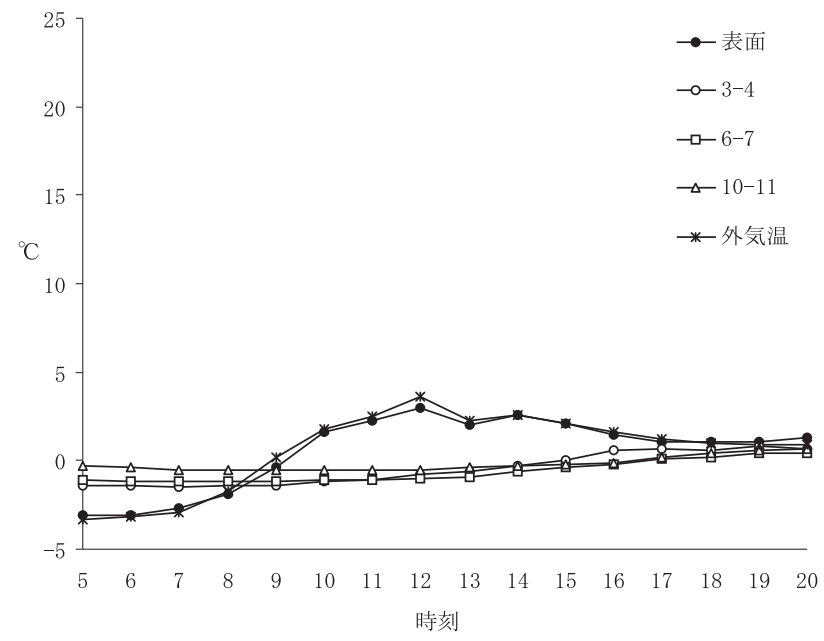

第 5 図＼cjkstart量天時のキャベッ結球内部の温度変化（2010 年 1 月 12 日)

3-4:3 枚目と 4 枚目の空隙 6-7: 6 枚目と 7 枚目の空隙 10-11: 10 枚目と 11 枚目の空隙

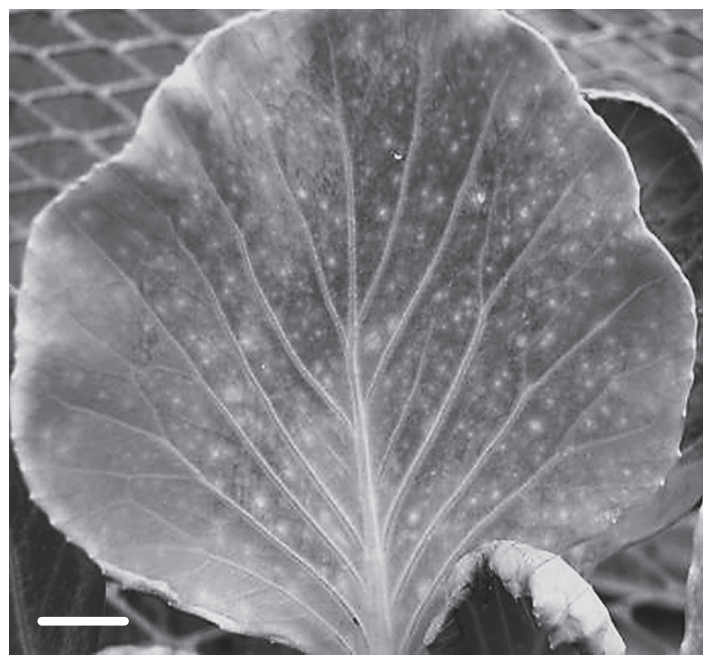

第 6 図 植水によるキャベッ幼葉上の斑点形成 $-5^{\circ} \mathrm{C}$ で植水処理 60 分後に $20^{\circ} \mathrm{C} 3$ 日処理したキャベッ幼葉 バーは $1 \mathrm{~cm}$

温度は最低温度は $-4.8^{\circ} \mathrm{C}$, 最高温度は $13.5^{\circ} \mathrm{C}$ であった. キャベッ結球内部の温度変化を第 4 図に示す. 2010 年 1 月 12日の観察地は量りでキャベッ近傍の䨌囲気温度は最低温 度は $-3.3^{\circ} \mathrm{C}$, 最高温度は $3.6^{\circ} \mathrm{C}$ であった。 キャベッ結球内 部の温度変化を第 5 図に示す.

\section{3. 植水がキャベツ葉の斑点形成に及ぼす影響}

植水の有無がキャベツ葉の斑点形成に及ぼす影響を調べ たところ, 植氷処理時間が 15 分区は斑点形成指数が 23.3, 30 分区では 30, 45 分区では 43.3，60 分区では 93.3 であっ た. 植水無しでは $-5^{\circ} \mathrm{C}, 60$ 分の低温処理でも斑点形成は 認められなかった（第 1 表）。植水処理 60 分後に $20^{\circ} \mathrm{C}$ に 移行した区の斑点形成を第 6 図に示す。また，植氷後の解 
第 1 表 植水がキャベツ葉の斑点形成に及ぼす影響

\begin{tabular}{lcccc}
\hline \hline \multirow{2}{*}{ 処理区 } & \multicolumn{4}{c}{ 斑点形成度 $^{\mathrm{z}}$} \\
\cline { 2 - 5 } & 15 分 $^{\mathrm{y}}$ & 30 分 & 45 分 & 60 分 \\
\hline 植水 & 23.3 & 30 & 43.3 & 93.3 \\
無処理 & 0 & 0 & 0 & 0 \\
\hline
\end{tabular}

${ }^{\mathrm{z}}$ : 斑点形成度 $=\Sigma$ (指数 $\times$ 株数) $/ 3 \times$ 調査株数 y : $-5^{\circ} \mathrm{C}$ 処理時間

供試品種は“あさしお’

数字は斑点の形成程度を指数で表し，0 は斑点なし，1 は斑 点が $1 / 3$ 以下の面積で認められ， 2 は斑点が $1 / 3 \sim 2 / 3$ の面 積で認められ，3はほぼ全葉で斑点形成が認められる

第 2 表 融解温度がキャベツ葉の斑点形成に及ぼす影響

\begin{tabular}{|c|c|}
\hline 処理区 $^{z}$ & 斑点形成度 ${ }^{y}$ \\
\hline $0^{\circ} \mathrm{C} 60$ 分 $\rightarrow 5^{\circ} \mathrm{C} 60$ 分 $\rightarrow 20^{\circ} \mathrm{C}^{\mathrm{x}}$ (緩融解) & 0 \\
\hline $0^{\circ} \mathrm{C} 60$ 分 $\rightarrow 20^{\circ} \mathrm{C}$ & 6.7 \\
\hline $5^{\circ} \mathrm{C} 60$ 分 $\rightarrow 20^{\circ} \mathrm{C}$ & 33.3 \\
\hline $20^{\circ} \mathrm{C}$ （急速融解） & 93.3 \\
\hline
\end{tabular}

${ }^{\mathrm{z}}$ : 植水後 $-5^{\circ} \mathrm{C}$ で 60 分凍結処理した後の融解条件

$\mathrm{y}:$ 斑点形成度 $=\Sigma$ (指数 $\times$ 株数) $/ 3 \times$ 調査株数

${ }^{\mathrm{x}}: 20^{\circ} \mathrm{C}$ で 3 日間処理

供試品種は“あさしお”

数字は斑点の形成程度を指数で表し，0 は斑点なし，1 は斑 点が $1 / 3$ 以下の面積で認められ， 2 は斑点が $1 / 3 \sim 2 / 3$ の面 積で認められ，3はほぼ全葉で斑点形成が認められる
凍時間が葉の斑点形成に及ぼす影響を調べたところ，急速 融解区では葉に斑点が形成されたが，緩融解区では葉に斑 点形成は認められなかった（第 2 表）.

\section{4. 植水による細胞死の再現}

植水処理をした幼苗の葉 10 枚のらち9枚でトリパンブ ルー染色により染色部位が認められ（第 7 図 A)，水滴を散 布した位置と類似していた。一方，植水処理をしない幼苗 の葉はすべてで染色部位が認められなかった（第７図 B). また，淿場で栽培したキャベッ葉でも染色部位が認められ た（第 7 図 C,D）.

\section{考察}

冬季に生存できる植物の凍結は細胞外凍結と考兄られる (酒井, 1982). 細胞外凍結では細胞間隙に氷晶が形成され, 細胞内の水は細胞間隙の水に移動し脱水される. その結果, 細胞内溶液は濃縮され凍結は阻止される（Asahina, 1956）。 やがて融解が起こると細胞に水分が戻り復元する. しかし 脱水により障害が引き起こされることもある（Sukumaran・ Weiser, 1972; Pearce, 2001)。 また, 脱水による障害が起こら ないときでも，融解速度が速いとき障害が起こる（吉田・ 酒井，1967）．Laurie・Palta（1991）は日射による急激な融 解が細胞を損傷させることを報告している，本試験では量
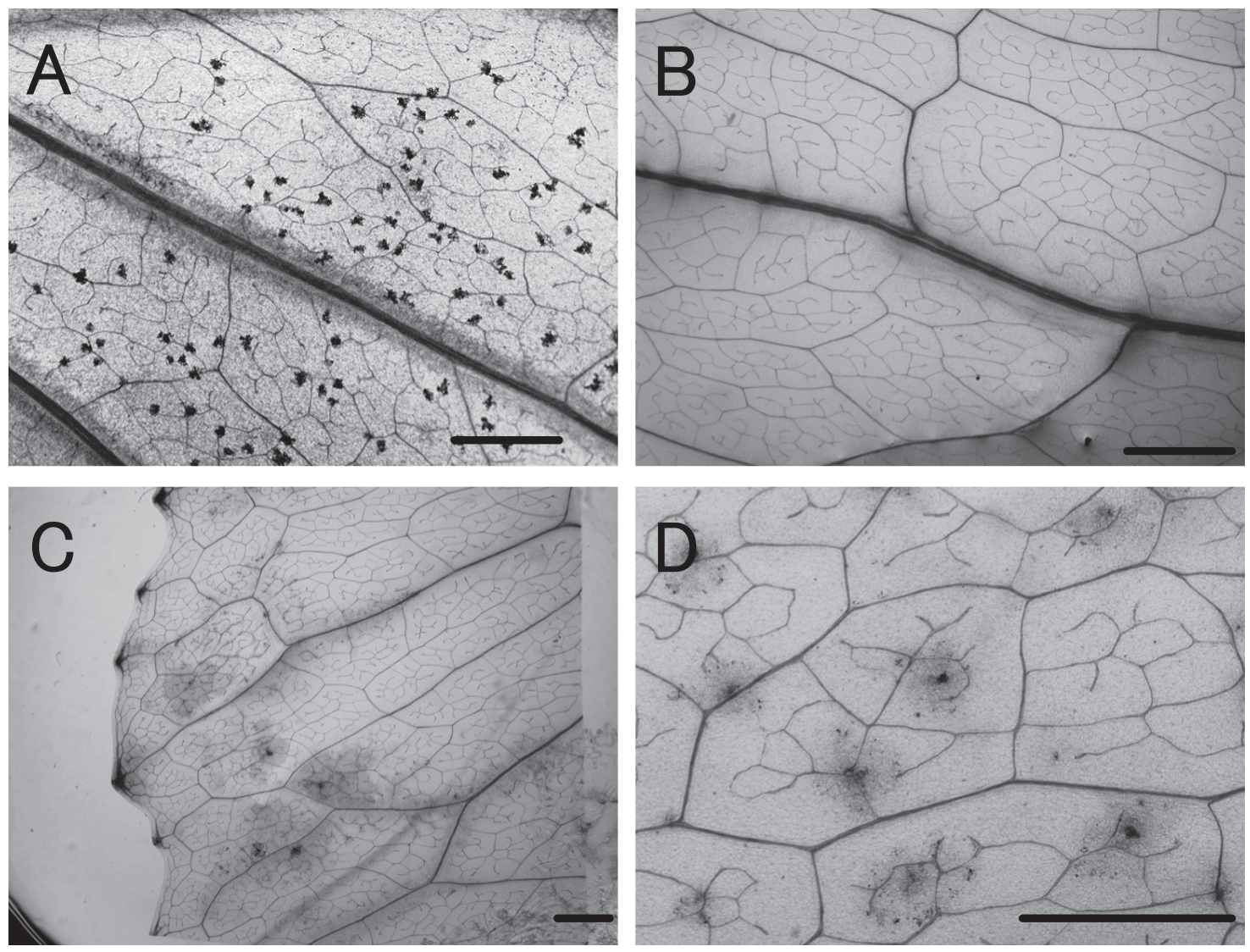

第 7 図 トリパンブルー染色によるキャベッ葉の細胞死の確認

$\mathrm{A}$ : 植水有 (幼苗), $\mathrm{B}$ : 植水無 (幼苗), $\mathrm{C}$ : 泀場結球葉, $\mathrm{D}$ : 同左拡大 バーは $5 \mathrm{~mm}$ 
天日のキャベッ結球内の温度変化はほとんどみられなかっ たが，晴天日は温度上昇がみられた（第 4，5図）。晴天日 の $7 \sim 9$ 時までの 2 時間の温度上昇は表面で $14.1^{\circ} \mathrm{C} ， 3$ 枚 目と 4 枚目の空隙で $21.8^{\circ} \mathrm{C}, 10$ 枚目と 11 枚目の空隙で $14.6^{\circ} \mathrm{C}$ 上昇し, 特に 3 枚目と 4 枚目の空隙の温度上昇が著 しく，氷の急激な融解が起こりやすい環境である。 また， 晴天時のキャベッでも日陰面では温度上昇がみられなかっ た (データ省略). このことは内部黒変症状が結球葉 $3 \sim 4$ 枚目に多発し，しかも局所的に症状が現れることと関連が あると考えられる. 結球内空隙では水滴の凍結が観察され， 観察中に変色痕がみられた（第２図）。これは北浦（1967） が桑で報告したよらにキャベッ葉面の水滴が凍結し，その 直下で過冷却が破壊され葉の凍結が起こっていたためと思 われる. キャベッ幼葉に水滴を散布し， $-5^{\circ} \mathrm{C} て ゙ 60$ 分（植 氷処理）後に $20^{\circ} \mathrm{C}$ で加温するとほぼ全葉で斑点が形成さ れ，植水しない区では斑点が形成されなかった（第 1 表）. さらに, 植氷しても融解速度の違いで斑点形成に差があり, $-5^{\circ} \mathrm{C}$ から $20^{\circ} \mathrm{C}$ 加温した急速融解区では斑点が現れ, 緩融 解区では斑点は形成されなかった。 このことは植氷により 葉表面の水塊と接する葉内の過冷却が破壊され, 斑点状に 凍結したためと思われ, キャベッ結球内で観察された変色 痕も凍結痕と考兄られる. そして, $-5^{\circ} \mathrm{C}$ から $20^{\circ} \mathrm{C}$ に加温 すると急激な融解が起こり, 細胞を損傷させるが, $0^{\circ} \mathrm{C}$ 付 近で緩やかに融解すると細胞は損傷することなく，元の状 態に復元される. 冬季浪場での観察により, キャベッ結球 葉では水滴による凍結は広範囲で起こっているが，急激な 融解は晴天時の日射部分で起こるため, 内部黒変症状が局 所的に発症すると考えられる. 実際の内部黒変症状の斑点 は暗茶色から黒色を示すことが多いが，幼苗を用いたポッ 卜試験では，白色系の斑点が形成された. Cox・Levitt (1976) はポット試験とフィールドでは結果が異なる場合があると 指摘して扣り, 結球葉と幼苗の葉の生育ステージや温度条 件が影響した可能性が考えられる。本試験では脱順化の影 響を検討していないが，佐々木ら（2002）は日射により葉 温が上昇し，脱順化を引き起こしていると報告しており， 脱順化の影響も考慮する必要がある.

急速な融解により細胞死が起きている可能性をトリパン ブルー染色法（Koch・Slusarenko, 1990）により死細胞を染 色して確認したところ, 植水し急速融解したキャベッ幼葉 は斑点状に染色された細胞が存在し（第 7 図 A), 死細胞が 確認された。 また，婸の結球しているキャベッについて， 肉眼では斑点が判別できない部位を同法で染色したとこ ろ，斑点状に死細胞が判別できた（第 7 図 C，D）。以上の ことから結球内空隙の水滴の凍結と急速融解は死細胞発生 の原因となることが明らかになった。 そして，キャベッ内 部黒変症状はこの現象による死細胞が痕跡となり斑点状に 症状が現れると推察される. このように内部黒変症状が水 滴の凍結と結球内の急激な温度上昇が連動して引き起こさ れるとするなら, その条件を緩和することで今後, 内部黒
変症状の発生を抑制し，具体的な対策を実施することが可 能と考えられる.

\section{摘 要}

寒害と思われるキャベッ内部黒変症状の発生原因究明を 目的に, 内部黒変症状発生個体の観察，キャベッ結球内部 の温度変化，植水がキャベッ葉の斑点形成に及ぼす影響に ついて検討した。 冬季のキャベッ結球内空隙では水滴の凍 結が観察された．結球内空隙では晴天時に急激な温度上昇 がみられた。キャベッ葉を $-5^{\circ} \mathrm{C} て ゙$ 植水すると 60 分でほぼ 全葉で斑点形成が認められた。凍結後, $-5^{\circ} \mathrm{C}$ から $20^{\circ} \mathrm{C}$ の 環境に移したところ，死細胞の発生が認められた．急激な 融解が細胞を損傷させたものと考えられた. このことから， 結球内空隙の水滴の凍結と急速融解は死細胞発生の原因と なることが明らかになり，キャベッ内部黒変症状はこの現 象による死細胞発生と関連があることが示唆された。

\section{引用文献}

青柳森一・神保信幸・所 重雄・村井正和. 1991. 冬春キャ ベッの寒害防止に関する研究，第 1 報産地における寒 害の発生実態とその発生条件の解明. 千葉農試研報. 32: 19-29.

Asahina, E. 1956. The freezing prosess of plant cell. Contrib. Inst. Low Temp. Sci. 10: 83-126.

Cox, W. and J. Levitt. 1969. Direct relation between growth and frosthardening in cabbage leaves. Plant Physiol. 44: 923928.

Cox, W. and J. Levitt. 1976. Interrelations between environmental factors and freezing resistance of cabbage leaves. Plant Physiol. 57: 553-555.

五十嵐大造・大林延夫．1985．夏まき冬どりキャベッの凍 害と腐敗病の関係について．神奈川園試研報．32: 3541 .

飯塚正英・村永順一郎・金井幸男．2009．冬どりキャベッ に打ける凍害発生の品種間差. 園学研. 8(別2)：509.

北浦 澄. 1967. 晚霜による桑の凍結および被害に関する 研究. 奛試報. 22: 207-327.

Koch, E. and A. Slusarenko. 1990. Arabidopsis is susceptible to infection by a downy mildew fungus. Plant Cell 2: 437-445.

Kohn, H. and J. Levitt. 1965. Frost hardiness studies on cabbage grown under controlled conditions. Plant Physiol. 40: 476480 .

Laurie S. W. and J. P. Palta. 1991. Influence of thaw rates on the level of injury by freeze-thaw stress in a cold hardy potato species. HortScience 26. 6: 732-733.

Pearce, R. S. 2001. Plant freezing and damage. Ann. Bot. 87: $417-424$.

Rajashekar, C. B., P. H. Li and J. V. Carter. 1983. Frost injury and heterogeneous ice nucleation in leaves of tuber-bearing 
solanum species ice nucleation activity of external source of nucleants. Plant Physiol. 71: 749-755.

酒井 昭. 1982. 植物の耐凍性と寒冷適応. 学会出版セン タ一。東京.

Sasaki, H., K. Ichimura, S. Imada and M. Oda. 2001. Loss of freezing tolerance associated with decrease in sugar concentrations by short-term deacclimation in cabbage seedlings. J. Japan. Soc. Hort. Sci. 70: 294-298.
佐々木英和・今田成雄・小田雅行. 2002. 遮光処理による キャベッの葉温低下と脱順化の抑制. 園学研. 1:133136.

Sukumaran, N. P. and C. J. Weiser. 1972. Freezing injury in potato leaves. Plant Physiol. 50: 564-567.

吉田静夫・酒井 昭. 1967. 植物の凍害におよぼす融解速 度の影響. 低温科學. 生物篇. 25: 71-79. 